\title{
PENGARUH RETURN ON ASSETS (ROA), RETURN ON EQUITY (ROE) \\ DAN CURRENT RATIO (CR) TERHADAP NILAI PERUSAHAAN DAN DAMPAKNYA TERHADAP KEBIJAKAN DEVIDEN (Studi kasus pada Perusahaan Construction and Engineering yang
}

\section{terdaftar di Bursa Efek Singapura)}

\author{
Jeni Irnawati ${ }^{1)}$ \\ 1) dosen universitas pamulang, email :jeni.irnawati@gmail.com
}

\section{ARTICLES \\ INFORMATION \\ JURNAL SEKURITAS \\ (Saham, Ekonomi, Keuangan dan Investasi ) \\ Vol.2, No.2, Januari 2019 \\ Halaman : 1-13 \\ C LPPM \& Prodi Manajemen \\ UNVERSITAS PAMULANG

$$
\begin{array}{ll}
\text { ISSN (online) } & : 2581-2777 \\
\text { ISSN (print) } & : 2581-2696
\end{array}
$$

\section{Keyword :}

ROA, ROE, CR, The value of company, and the dividen policy income

JEL. classification : C33, G21, G24, N15, N25

\section{Contact Author :}

PRODI MANAJEMEN UNPAM

JL.Surya Kencana No.1 Pamulang

Tangerang Selatan - Banten

Telp. (021) 7412566, Fax (021) 7412491 Email :

jurnalfinance.unpam@gmail.com
Tujuan penelitian ini untuk mengetahui Return On Assets (ROA) berpengaruh terhadap Nilai Perusahaan, mengetahui Return On Equity (ROE) berpengaruh terhadap Nilai Perusahaan, mengetahui pengaruh Current Ratio (CR) berpengaruh terhadap Nilai Perusahaan, mengetahui pengaruh Return On Assets (ROA), Return On Equity (ROE), dan Current Ratio (CR) secara simultan terhadap Nilai Perusahaan. Metode penelitian yang digunakan dalam penelitian ini adalah metode deskriptif, Pengujian asumsi klasik yang dilakukan terdiri atas uji normalitas, uji autokorelasi, uji multikolinearitas, dan uji heteroskedastisitas. Uji Regresi Linier Berganda, Uji Koefisien Korelasi, Uji Koefisien Determinasi, dan Uji Hipotesis. Hasil Penelitiannya adalah: (1) Terdapat pengaruh Return On Assets (ROA) terhadap Nilai Perusahaan, (2) Terdapat pengaruh Return On Equity (ROE) terhadap nilai perusahaan, (3) Terdapat pengaruh Current Ratio (CR) terhadap nilai perusahaan, (4) Terdapat pengaruh Return On Assets (ROA), Return On Equity (ROE) dan Current Ratio (CR) secara simultan terhadap nilai perusahaan, (5) Terdapat pengaruh Nilai Perusahaan terhadap Kebijakan Deviden

The purpose of this study to determine the Return On Assets (ROA) effect on the value of company, knowing Return On Equiry (ROE) effect on the value of company, knowing Current Ratio (CR) effect on the value of company, know the influence Return On Assets (ROA), Return On Equiry (ROE) and Current Ratio (CR) simultaneously against the value of company. The research method used in this research is descriptive method. The classical assumption test consisted of normality test, autocorrelation test, multicolinearity test, and heteroscedasticity test. Multiple Linear Regression Test, Correlation Coefficient Test, Determination Coefficient Test, and Hypothesis Test. The result of research are: (1) There is influence of Return On Assets (ROA) to the value of company, (2) There is influence of Return On Equiry (ROE) to the value of company, (3) There is influence of Current Ratio $(C R)$ to the value of company, (4) There is influence of Return On Assets (ROA), Return On Equiry (ROE), and Current Ratio (CR) simultaneously to the value of company Price, (5) There is influence of the value of company to the dividen policy. 


\section{A. Pendahuluan}

Pada era globalisasi,dapat mengakibatkan terjadinya perkembangan di berbagai bidang,terutama di bidang ekonomi. Perkembangan ekonomi atau bisnis yang terjadi, menyebabkan setiap perusahaan berlomba memaksimalkan laba yang dihasilkan untuk meningkatkan nilai perusahaan. Nilai perusahaan merupakan sesuatu yang sangat penting bagi perusahaan, karena nilai perusahaan dapat mencerminkan kinerja dari perusahaan (Fahmi, 2013:308). Untuk meningkatkan nilai perusahaan dapat dilakukan dengan tata kelola perusahaan yang baik dan pelaksanaan fungsi manajemen keuangan secara optimal, dimana satu keputusan keuangan yang diambil akan mempengaruhi keputusan keuangan lainnya dan berdampak pada nilai perusahaan. Nilai perusahaan pada dasarnya dapat diukur melalui beberapa aspek, salah satunya adalah harga pasar saham perusahaan, karena harga pasar saham perusahaan mencerminkan penilaian investor keseluruhan atas setiap ekuitas yang dimiliki (Nugroho, 2015).

Menurut (Sutrisno, 2007:4) bahwa tujuan perusahaan adalah meningkatkan kemakmuran pada pemegang saham diperlihatkan dalam wujud semakin tingginya harga saham yang merupakan pencerminan dari keputusan-keputusan investasi, pendanaan dan kebijakan deviden. Oleh karena itu kemakmuran para pemegang saham dapat dijadikan sebagai dasar analisis dan tindakan rasional dalam proses pembuat keputusan. Selain itu, tujuan utama dari perusahaan adalah meningkatkan nilai perusahaan. Untuk meningkatkan nilai perusahaan tersebut dapat dicapai maka perusahaan tersebut harus beroperasi secara maksimal untuk mencapai keuntungan yang ditargetkan.

Return On Asset (ROA) atau pengembalian Asset, bahwa dibeberapa referensi lainnya rasio ini juga ditulis dengan Rasio Return On Investment (ROI) Rasio ini melihat sejauh mana investasi yang telah ditanamkan mampu memberikan pengembalian keuntungan sesuai dengan yang diharapkandan investasi tersebut sebenarnya sama dengan asset perusahaan yang ditanamkan atau ditempatkan. (Munawir, 2010)

Sedangakan ROE menunjukkan kemampuan perusahaandalam menghasilkan laba yang dapatdibagikan kepada pemegang saham. Semakin besar ROE maka semakin bagus karena perusahaan secara efektif meng-gunakan ekuitas untuk menghasilkan labadan sebaliknya. Hal ini sesuai dengan teori Signaling Hypothesis yang menyatakan bahwa investor menganggap perubahan dividen ditangkap sebagai sinyal mengenai penghasilan yang baik di masa mendatang (Atmaja, 2008: 287).

Faktor lain yang mempengaruhi nilai perusahaan adalah current ratio. Menurut Jumingan, 2008:123-124, Rasio yang umum sering digunakan dalam analisis laporan keuangan adalah rasio lancar (Current Ratio). Dalam mengukur rasio modal kerja yang penting bukan besar kecilnya perbedaan aktiva lancar dengan utang jangka pendek (modal kerja neto) melainkan harus dilihat pada hubungannya dan perbandingannya yang mencerminkan kemampuan mengembalikan utang. Current ratio yang tinggi mungkin menunjukkan adanya uang kas yang berlebihan dibanding dengan tingkat kebutuhan atau adanya unsur aktiva lancar yang rendah likuiditasnya (seperti persediaan) yang berlebihlebihan. Current ratio yang tinggi tersebut memang baik dari sudut pandang kreditur, tetapi dari sudut pandangan pemegang saham kurang menguntungkan karena aktiva lancar tidak didayagunakan dengan efektif. Sebaliknya current ratio yang rendah relatif lebih riskan, tetapi menunjukkan bahwa manajemen telah mengoperasikan aktiva lancar secara efektif. Saldo kas dibuat minimum sesuai dengan kebutuhan dan tingkat perputaran piutang dan persediaan diusahakan maksimum.

Beberapa penelitian terdahulu yang terkait dengan ROA, ROE dan CR memberikan hasil yang beragam. Penelitian yang dilakukan oleh Meythi, 2012 yang meneliti tentang Pengaruh Profitabilitas dan Kesempatan Investasi Terhadap Kebijakan Deviden Dengan Likuiditas Sebagai Variabel Moderating Pada Emiten Pembentuk LQ 45 menunjukkan bahwa peluang profitabilitas yaitu Return On Assets (ROA) dan investasi tidak mempengaruhi Dividen Payout Ratio parsial dan simultan terhadap likuiditas (Current Ratio) sebagai variabel moderator. Sedangkan penelitian yang dilakukan Alfredo 
Mahendra DJ, 2011 yang meneliti tentang Pengaruh Kinerja Keuangan Terhadap Nilai Perusahaan (kebijakan deviden sebagai variabel moderating) Pada Perusahaan Manufaktur di BEI menunjukkan bahwa hanya profitabilitas berpengaruh terhadap nilai perusahaan.

Disisi lain, penelitian yang dilakukan oleh (JSP, 2003) yang meneliti mengenai Pengaruh ROA, ROE, EPS, Profit Margin, Assets Turnover, Rasio Leverage, dan DER terhadap Return Saham Pada Perusahaan LQ 45 di BEl. Hasil dari penelitian ini menunjukkan bahwa ROA, ROE berpengaruh terhadap harga saham.

\section{B. Perumusan Masalah}

1. Bagaimana ROA berpengaruh terhadap Nilai Perusahaan?

2. Bagaimana ROE berpengaruh terhadap Nilai Perusahaan?

3. Bagaimana CR berpengaruh terhadap Nilai Perusahaan?

4. Bagaimana pengaruh ROA, ROE dan CR terhadap Nilai Perusahaan?

5. Bagaimana Nilai Perusahaan berpengaruh terhadap Kebijakan Deviden?

\section{Tujuan Penelitian}

1. Mengetahui Mengetahui ROA berpengaruh terhadap Nilai Perusahaan.

2. Mengetahui ROE berpengaruh terhadap Nilai Perusahaan.

3. Mengetahui CR berpengaruh terhadap Nilai Perusahaan.

4. Mengetahui pengaruh ROA, ROE dan CR terhadap Nilai Perusahaan.

5. Mengetahui pengaruh Nilai Perusahaan terhadap Kebijakan Deviden.

\section{Landasan Teori}

\subsection{Nilai Perusahaan}

Menurut Nugroho (2012), Nilai perusahaan adalah nilai wajar perusahaan yang menggambarkan persepsi investor terhadap emiten tertentu, sehingga nilai perusahaan merupakan persepsi investor terhadap perusahaan yang selalu dikaitkan dengan harga saham. Dalam penelitian ini Nilai Perusahaan diukur dengan EPS (Earning Per Share)

\subsection{ROA (Return On Assets)}

Rasio ini mengukur efektivitas manajemen secara keseluruhan yang ditunjukan oleh besar kecilnya tingkat keuntungan yang diperoleh dalam hubungannya dengan penjualan atau investasi. Semakin baik rasio profitabilitas maka semakin baik menggambarkan kemampuan tingginya peroleh keuntungan perusahaan (Irham Fahmi, 2011:68).

$$
\text { Return On Assets }=\frac{\text { Laba Bersih }}{\text { Total Aktiva }} x 100
$$

\subsection{ROE (Return On Equity)}

Perolehan laba perusahaan diukurmenggunakan rasio profitabilitasyakni salahsatunya dapat menggunakan Return On Equity (ROE). ROE merupakan rasio lababersih terhadap ekuitas yang mengukur tingkat pengembalian pemegang saham (Brigham\&Houston, 2010:149).

Return On Equity $=\frac{\text { Laba Bersih }}{\text { Total Aktiva }} \times 100$




\subsection{CR (Current Ratio)}

Current ratio yang rendah biasanya dianggap menunjukkan terjadinya masalah dalam likuidasi, sebaliknya current ratio yang terlalu tinggi juga kurang bagus, karena menunjukkan banyaknya dana menganggur yang pada akhirnya dapat mengurangi kemampuan perusahaan (Sawir, 2009:10).

$$
\text { Current Ratio }(C R)=\frac{\text { Current Assets }}{\text { Current Liabilities }} x 100
$$

\subsection{Kebijakan Deviden}

Kebijakan dividen merupakan salah satu keputusan yang paling penting dalam perusahaan. Pembagian dividen seringkali menjadi suatu kekhawatiran yang dihadapi oleh yang positif. Investor menganggap manajer perusahaan tidak dapat menganalisa peluang investasi yang akan mendatangkan keuntungan, namun lebih memilih membagikan dividen kepada pemegang saham (Deitiana, 2013, h.78). Dalam penelitian ini Kebijakan Deviden diwakili dengan DPR (Dividen Payout Ratio).

\section{E. Metodologi}

Penelitian ini dilakukan dengan metode kuantitatif sedangkan metode pengolahan datanya adalah analisis regresi data panel dengan menggunakan software pengolah data statistik Eviews 9.0. Data yang diperoleh merupakan data sekunder berdasarkan laporan keuangan dalam kurun waktu 3 tahun yaitu dari tahun 2013-2016. Populasi yang digunakan dalam penelitian ini adalah seluruh perusahaan Construction and Engineering yang terdaftar di Bursa Efek Singapura (SGX) tahun 2013-2016 sebanyak 29 perusahaan. Sampel yang digunakan dalam penelitian ini berdasarkan kriteria perusahaan yang menerbitkan laporan keuangan dari tahun 2013-2015 sebanyak 10 perusahaan. Kriteria selanjutnya adalah perusahaan yang memiliki nilai ROA, ROE, CR, EPS dan DPR positif selama 4 tahun berturut-turut dari tahun 2013 sampai tahun 2016.

\section{F. Hasil dan Pembahasan}

Metode analisis data yang digunakan dalam penelitian ini adalah metode statistik dengan menggunakan software pengolah data statistik Eviews 9.0

\section{Uji Asumsi Klasik}

a. Uji Normalitas

Uji normalitas ini bertujuan untuk menguji apakah dalam model regresi panel variabel-variabelnya berdistribusi normal atau tidak. Model regresi yang baik adalah memiliki distribusi data normal atau mendekati normal. Tidak terpenuhinya normalitas pada umumnya disebabkan karena distribusi data yang di analisis tidak normal, karena terdapat nilai eksterm pada data yang diambil. Nilai ekstrem ini dapat terjadi karena adanya kesalahan dalam pengambilan sampel, bahkan karena kesalahan dalam melakukan input data atau karena karakteristik data tersebut sangat jauh dari rata-rata. (Suliyanto, 2011:69). 


\section{Gambar 4.1}

Uji Normalitas ROA, ROE, dan CR terhadap Nilai Perusahaan

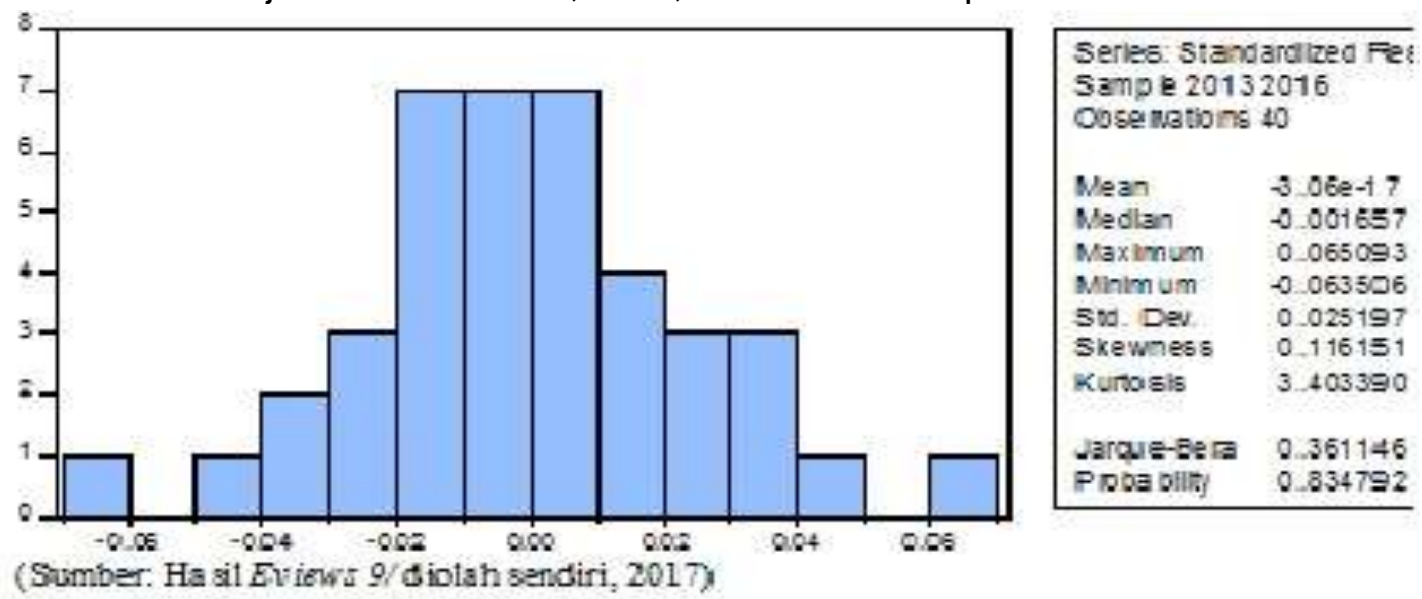

Berdasarkan hasil output dari data di atas menunjukkan bahwa pengaruh variabel ROA, ROE dan CR terhadap variabel nilai perusahaan menunjukkan nilai jarque-bera sebesar 0,361146. Untuk hasil analisis yang dihasilkan dari data pengolahan Uji Normalitas dilihat bahwa nilai probability $(0,361146)>$ tingkat signifikan $(0,05)$ maka hipotesis yang digunakan dalam Uji Normalitas adalah $\mathrm{Ho}$ diterima dan $\mathrm{H}_{1}$ ditolak maka dapat disimpulkan bahwa data dari hasil pengujian pengaruh variabel $R O A, R O E$, dan $C R$ terhadap nilai perusahaan berdistribusi normal.

\section{b. Uji Multikolinearitas}

Uji Multikolinearitas bertujuan untuk menguji apakah model regresi ditemukan adanya korelasi antara variabel bebas yaitu Kredit, CAR dan NPL. Multikolinearitas adalah kondisi adanya hubungan linier antarvariabel independen. Karena melibatkan beberapa variabel independen, maka multikolinearitas tidak akan terjadi pada persamaan regresi sederhana (Winarno, 2015:5.1).

Tabel 4.1

Nilai koefisien korelasi dari hasil uji multikolinearitas Antara variabel ROA, ROE dan CR

\begin{tabular}{|l|l|l|l|}
\hline & ROA & LOGROE & CR \\
\hline ROA & $1,000,000$ & 0,775254 & 0,105587 \\
\hline LOGROE & 0,775254 & $1,000,000$ & 0,020446 \\
\hline CR & 0,105587 & 0,020446 & $1,000,000$ \\
\hline
\end{tabular}

(Sumber: Hasil Eviews 9/ diolah sendiri, 2017)

Berdasarkan tabel 4.1 diatas tidak terdapat nilai koefisien korelasi yang lebih besar dari 0,80 sehingga uji ini membuktikan tidak terjadi multikolinieritas antar variabel independen ROA, ROE dan CR. Dikarenakan pada persamaan regresi sederhana tidak terjadi multikolinieritas sehingga tidak perlu dilakukan uji multikolinieritas pada regresi sederhana. 


\section{c. Uji Autokorelasi}

Menurut (Winarno, 2015: 5.29) autokorelasi adalah hubungan antara residual satu observasi dengan residual observasi lainnya. Autokorelasi lebih mudah timbul pada data yang bersifat runtut waktu (time series), karena berdasarkan sifatnya data masa sekarang dipengaruhi oleh data pada masa-masa sebelumnya. Meskipun demikan, tetap dimungkinkan autokorelasi dijumpai pada data yang bersifat antar objek (cross section). Pengujian autokorelasi salah satunya dapat dilakukan dengan menggunakan metode Uji Durbin Watson dan Uji Breusch Godfrey. Yang peneliti gunakan dalam penelitian ini adalah Uji Durbin Watson (Uji D-W) merupakan salah satu uji yang banyak dipakai untuk mengetahui ada tidaknya autokorelasi.

Tabel 4.2

Uji Autokorelasi dengan Durbin Watson antara variabel ROA, ROE dan CR terhadap Nilai Perusahaan

\begin{tabular}{|c|c|c|c|c|}
\hline $\begin{array}{l}\text { F-statis fic } \\
\text { Obs-R-squared }\end{array}$ & $\begin{array}{l}4.000375 \\
7.619626 \\
\end{array}$ & \multicolumn{2}{|c|}{$\begin{array}{l}\text { Prob. } F(z, 34) \\
\text { Prob. Chi-Square( }(2)\end{array}$} & $\begin{array}{l}0.0275 \\
0.0222 \\
\end{array}$ \\
\hline \multicolumn{5}{|c|}{$\begin{array}{l}\text { Test Equation: } \\
\text { Dependent Variable: RESID } \\
\text { Method: Least Squares } \\
\text { Date: } 09 \text { 107/7 Time: } 22: 55 \\
\text { Sample: } 20132052 \\
\text { Included observations: } 40 \\
\text { Presa mple mis sing value lagged residuals set to zero. }\end{array}$} \\
\hline Variable & Coefficient & Std: Error. & t-States fic & Prob. \\
\hline $\begin{array}{c}\mathrm{C} \\
\mathrm{ROA} \\
\mathrm{ROE} \\
\mathrm{CR} \\
\text { RESID }(-1) \\
\text { RESID }(-2)\end{array}$ & $\begin{array}{r}-0.001718 \\
5.50 \mathrm{E}-07 \\
1.02 \mathrm{E}-08 \\
-4.87 \mathrm{E}-07 \\
0.482912 \\
-0.182998\end{array}$ & $\begin{array}{l}0.011657 \\
1.50 \mathrm{E}-06 \\
3.91 \mathrm{E}-07 \\
4.89 \mathrm{E}-06 \\
0.171012 \\
0.177390\end{array}$ & $\begin{array}{r}-0.147376 \\
0.365740 \\
0.026204 \\
-0.103755 \\
2.823847 \\
-1.031613\end{array}$ & $\begin{array}{l}0.8837 \\
0.7168 \\
0.9792 \\
0.9180 \\
0.0079 \\
0.3095\end{array}$ \\
\hline $\begin{array}{l}\text { R-squared } \\
\text { Adjusted R-squared } \\
\text { S.E. ofregression } \\
\text { Sum squared resid. } \\
\text { Log likelihood } \\
\text { F-stats tic } \\
\text { Prob(F-statisfic) }\end{array}$ & $\begin{array}{l}0.190491 \\
0.071445 \\
0.032107 \\
0.035049 \\
84.04039 \\
1.600150 \\
0.188588\end{array}$ & \multicolumn{2}{|c|}{$\begin{array}{l}\text { Mean dependent var } \\
\text { S.D. dependent var } \\
\text { Acaike in } 6 \text { criterion } \\
\text { Sohwa rz oriterion } \\
\text { Hanna n-Quinn oriter. } \\
\text { Durbin-Wats on s tat }\end{array}$} & $\begin{array}{r}-5.12 E-18 \\
0.033319 \\
-3.902020 \\
-3.648888 \\
-3.810423 \\
1.925812\end{array}$ \\
\hline
\end{tabular}

(Sumber: Hasil Eviews Q/ diolah sendiri, 2017)

Dari pengujian autokorelasi pada tabel 4.2 di atas didapatkan nilai Durbin Watson hasil regresi pada penelitian ini sebesar 1,925812 yang mana nilai tersebut berada diantara 1,54 sampai dengan 2,46 sehingga sesuai dengan ketentuan pada tabel 4.2 di atas maka model regresi ini tidak ada autokorelasi.

\section{d. Uji Heteroskedastisitas}

Menurut (Sarjono,Julianita, 2011:66), Uji Heteroskedastisitas menunjukkan bahwa varian variabel tidak sama untuk semua pengamatan atau observasi. Jika varian dari satu residual pengamatan ke pengamatan lain tetap maka disebut homokedastisitas dan jika varian residual dari pengamatan satu ke pengamatan lain berbeda maka disebut heteroskedastisitas. Akibat adanya heteroskedastisitas adalah jika terjadi perubahan 
variabel terikat maka residualnya akan berubah sejalan kenaikan atau penurunannya dengan konsekuensi jika variabel terikat bertambah maka kesalahan juga bertambah. Untuk mengetahui apakah ada atau tidaknya heteroskedastisitas dilakukan dengan uji glejser dengan indikator terjadi atau tidaknya heteroskedastisitas. Dengan melihat angka signifikansi dari hasil regresi nilai absolut residual terhadap variabel independen, (Ghozali, 2003:142).

\section{Tabel 4.3}

Uji Heteroskedastisitas dengan Metode Uji Glejser antara variabel ROA, ROE dan CR terhadap Nilai Perusahaan

Heteroskedas ficityTest Gleiser

\begin{tabular}{|c|c|c|c|c|}
\hline $\begin{array}{l}\text { F-s tafsic } \\
\text { Obs*R-squared } \\
\text { Scaled explained SS }\end{array}$ & $\begin{array}{l}3.574525 \\
9.180440 \\
10.72570 \\
\end{array}$ & \multicolumn{2}{|c|}{$\begin{array}{l}\text { Prob. } \mathrm{R} 3,38\} \\
\text { Prob. Chi-Square(3) } \\
\text { Prob. Chi-Square }(3)\end{array}$} & $\begin{array}{l}0.0232 \\
0.0270 \\
0.0133\end{array}$ \\
\hline \multicolumn{5}{|c|}{$\begin{array}{l}\text { TestEquation: } \\
\text { Dependent Vanable: ARESID } \\
\text { Method: Least Squares } \\
\text { Date:09/07/17 Time: } 22: 56 \\
\text { Sample: } 20132052 \\
\text { In du ded obsenations: } 40\end{array}$} \\
\hline Variable & Coefficient & St. Error & t-Statistic & Prob. \\
\hline $\begin{array}{l}\mathrm{C} \\
\mathrm{ROA} \\
\mathrm{ROE} \\
\mathrm{CR}\end{array}$ & $\begin{array}{r}0.007907 \\
-1.11 \mathrm{E}-06 \\
4.40 \mathrm{E}-07 \\
7.56 \mathrm{E}-00\end{array}$ & $\begin{array}{l}0.007509 \\
9.56 \mathrm{E}-07 \\
2.54 \mathrm{E}-07 \\
3.03 \mathrm{E}-06\end{array}$ & $\begin{array}{r}1.052940 \\
-1.159430 \\
1.730922 \\
2.492700\end{array}$ & $\begin{array}{l}0.2994 \\
0.2539 \\
0.0920 \\
0.0174\end{array}$ \\
\hline $\begin{array}{l}\text { R-squared } \\
\text { Adjusted R-squared } \\
\text { S.E. of reares sion } \\
\text { Sum squared resid } \\
\text { Log likelihood } \\
\text { F-stefsto } \\
\text { ProbfF-statistich }\end{array}$ & $\begin{array}{l}0.229511 \\
0.165304 \\
0.020907 \\
0.015736 \\
100.0580 \\
3.574525 \\
0.023201\end{array}$ & \multicolumn{2}{|c|}{$\begin{array}{l}\text { Mean dependent var } \\
\text { S.D. dependent var } \\
\text { Akaikeinfo criterion } \\
\text { Schwar criterion } \\
\text { Hannan-Quinn criter. } \\
\text { Durbin-Watson stat }\end{array}$} & $\begin{array}{r}0.023913 \\
0.022884 \\
-4.802799 \\
-4.633912 \\
-4.741735 \\
1.539979\end{array}$ \\
\hline
\end{tabular}

(Sumber: Hasil Eviews 9/diolah sendiri, 2017)

Pengujian ini dilakukan dengan menggunakan program eview versi 9 yang akan memperoleh nilai probabilitas dan akan dibandingkan dengan tingkat signifikansi (alpha). Adapun ketentuan dalam memberikan kesimpulan terjadi atau tidaknya Heteroskedastisitas adalah dengan Uji Glejser dan akan didapatkan nilai absolut. Nilai probabilitas ROA sebesar $(0,2539)$, ROE sebesar $(0,0920)$ dan nilai CR sebesar $(0,0174)$. Jika nilai probabilitas variabel independen lebih besar dari $\alpha=5 \%$ maka dapat disimpulkan tidak terjadi Heteroskedastisitas. 


\section{Pengujian Hipotesis}

a. Pengujian Secara Parsial (Uji t)

\section{Tabel 4.4}

\section{Pengaruh ROA terhadap Nilai Perusahaan}

\begin{tabular}{|c|c|c|c|c|}
\hline \multicolumn{5}{|c|}{ 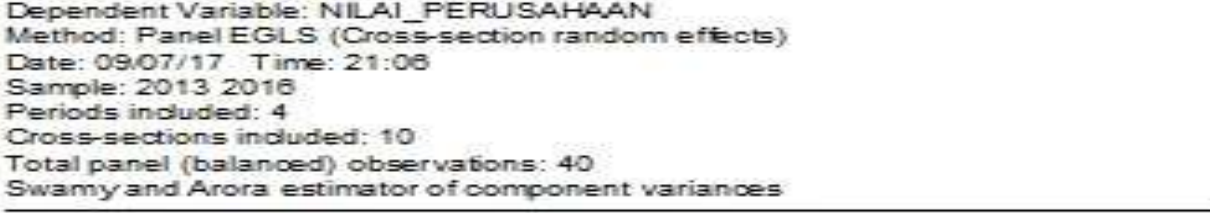 } \\
\hline Vanabie & Coefficient & Std. Error & t-Statesto & Prob. \\
\hline ROA & $\begin{array}{l}0.024622 \\
0.004958\end{array}$ & $\begin{array}{l}0.013210 \\
0.001455\end{array}$ & $\begin{array}{l}1.863904 \\
3.407862\end{array}$ & $\begin{array}{l}0.0701 \\
0.0011\end{array}$ \\
\hline \multicolumn{5}{|c|}{ Efrects Specification: } \\
\hline $\begin{array}{l}\text { Grosssection randiom } \\
\text { ldiosyncratio random }\end{array}$ & & & $\begin{array}{l}0.029955 \\
0.033402\end{array}$ & $\begin{array}{l}0.4457 \\
0.5543\end{array}$ \\
\hline \multicolumn{5}{|c|}{ Weighted Stafistics } \\
\hline $\begin{array}{l}\text { R-squared } \\
\text { Adjusted R-squared } \\
\text { S.E. of regression } \\
\text { F-statistic } \\
\text { Prob(F-statistic) }\end{array}$ & $\begin{array}{l}0.234204 \\
0.214051 \\
0.033391 \\
11.82158 \\
0.001557\end{array}$ & \multicolumn{2}{|c|}{$\begin{array}{l}\text { Mean dependent var } \\
\text { S.D. dependent var } \\
\text { Sum squared resid } \\
\text { Durbin-W Wation stat }\end{array}$} & $\begin{array}{l}0.024507 \\
0.037864 \\
0.042388 \\
2.095358\end{array}$ \\
\hline \multicolumn{5}{|c|}{ Unneighted Statsstics } \\
\hline $\begin{array}{l}\text { R-squared } \\
\text { Sum squared resid }\end{array}$ & $\begin{array}{l}0.122138 \\
0.074110\end{array}$ & $\begin{array}{l}\text { Mean diepen } \\
\text { Durbin-Vvate }\end{array}$ & $\begin{array}{l}\text { ver } \\
\text { tet }\end{array}$ & $\begin{array}{l}0.050325 \\
1.197892\end{array}$ \\
\hline
\end{tabular}

Berdasarkan tabel 4.4 hasil pengujian analisis regresi data panel secara parsial menunjukkan hasil t-hitung 3,407862. Sementara t-tabel dengan $a=5 \%$ dan df $(n-k)=(40-$ $4)=36$, maka t-tabel $(0,05 ; 36)=2,02809$. Sehingga t-hitung lebih besar dari t-tabel $(3,407862>2,02809)$ jadi Ho ditolak dan Ha diterima sehingga dapat disimpulkan bahwa variabel kredit berpengaruh secara nyata terhadap variabel pendapatan bunga. Kemudian nilai probabilitas ROA lebih kecil dari konstanta $(0,0016<0,05)$ maka hasilnya terdapat pengaruh signifikan dari variabel $\mathrm{ROA}$ secara individual terhadap nilai perusahaan.

\section{Tabel 4.5}

\section{Pengaruh ROE terhadap Nilai Perusahaan}

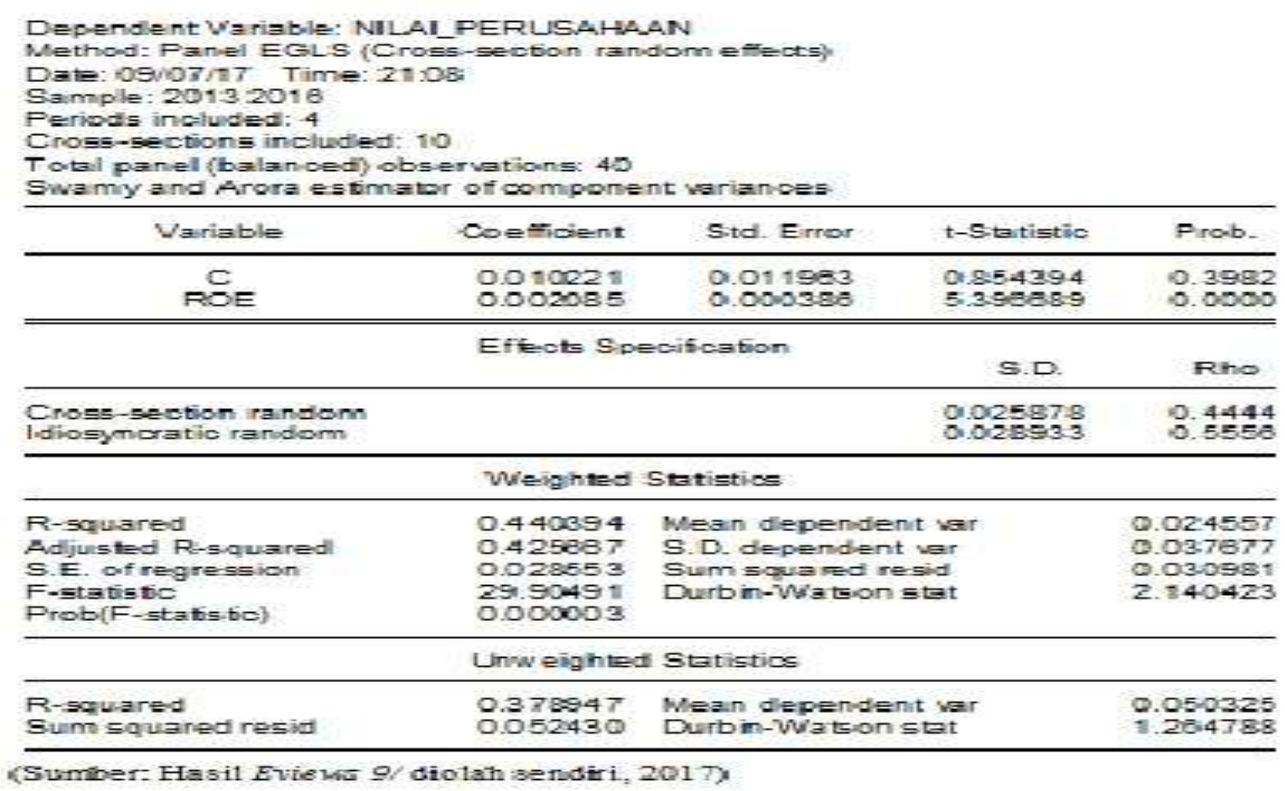


Berdasarkan 4.5 hasil pengujian analisis regresi data panel secara parsial menunjukkan hasil t-hitung 5,396689. Sementara t-tabel dengan $a=5 \%$ dan df $(n-k)=(40-$ $4)=36$, maka t-tabel $(0,05 ; 36)=2,02809$. Sehingga t-hitung lebih besar dari t-tabel $(5,396689>2,02809)$ jadi Ho ditolak dan Ha diterima sehingga dapat disimpulkan bahwa variabel $\mathrm{ROE}$ berpengaruh secara nyata terhadap variabel nilai perusahaan. Kemudian nilai probabilitas ROA lebih kecil dari konstanta $(0,0000<0.05)$ maka hasilnya terdapat pengaruh signifikan dari variabel $\mathrm{ROE}$ secara individual terhadap nilai perusahaan.

Tabel 4.6

\begin{tabular}{|c|c|c|c|c|}
\hline \multicolumn{5}{|c|}{$\begin{array}{l}\text { Dependent Variable: NILAI_PERUSAHAAN } \\
\text { Method: PanelEGLS (Cross-section random effects) } \\
\text { Date: } 0907 / 17 \text { Time: } 21: 12 \\
\text { Sample: } 20132016 \\
\text { Periods induded: } 4 \\
\text { Cross sections included: } 10 \\
\text { Total panel (balanced) observabons: } 40 \\
\text { Swamyand Arora estimator of component variances }\end{array}$} \\
\hline Variabie & Coefficient & Std. Error & t-Statesco & Prob. \\
\hline \multirow[t]{2}{*}{$\mathrm{CR}$} & $\begin{array}{r}-0.011994 \\
0.030391\end{array}$ & $\begin{array}{l}0.0173388 \\
0.007272\end{array}$ & $\begin{array}{r}-0.690541 \\
4.179383\end{array}$ & $\begin{array}{l}0.4941 \\
0.0002\end{array}$ \\
\hline & \multicolumn{2}{|c|}{ Effects Specification: } & S.D. & Rho: \\
\hline \multirow[t]{2}{*}{$\begin{array}{l}\text { Crosssection randiom } \\
\text { ldiosyncrafic random }\end{array}$} & & & $\begin{array}{l}0.022923 \\
0.032729\end{array}$ & $\begin{array}{l}0.3291 \\
0.8709\end{array}$ \\
\hline & \multicolumn{3}{|c|}{ Weighted Stafistics } & \\
\hline $\begin{array}{l}\text { R-squared } \\
\text { Adjusted R-squared } \\
\text { S.E. of regression } \\
\text { F-statistic } \\
\text { Prob(F-statistic) }\end{array}$ & $\begin{array}{l}0.316288 \\
0.298293 \\
0.032825 \\
17.57878 \\
0.000159\end{array}$ & \multicolumn{2}{|c|}{$\begin{array}{l}\text { Mean dependent var } \\
\text { S.D. de pendent var } \\
\text { Sum squared resid } \\
\text { Durbin-Vatson stat }\end{array}$} & $\begin{array}{l}0.029240 \\
0.038947 \\
0.040446 \\
1.772082\end{array}$ \\
\hline \multicolumn{5}{|c|}{ Unweighted Stafifics } \\
\hline $\begin{array}{l}\text { R-squared } \\
\text { Sum squared resid }\end{array}$ & $\begin{array}{l}0.310569 \\
0.058202\end{array}$ & $\begin{array}{l}\text { Mean depend } \\
\text { Durbin-Wated }\end{array}$ & $\begin{array}{l}\text { ot var } \\
\text { Etat }\end{array}$ & $\begin{array}{l}0.050325 \\
1.231465\end{array}$ \\
\hline
\end{tabular}

Berdasarkan tabel 4.6 hasil pengujian analisis regresi data panel secara parsial menunjukkan hasil t-hitung 4,179383. Sementara t-tabel dengan a $=5 \%$ dan df $(n-k)=(40-$ $4)=36$, maka t-tabel $(0,05 ; 36)=2,02809$. Sehingga t-hitung lebih besar dari t-tabel $(4,179383>2,02809)$ jadi Ho ditolak dan Ha diterima sehingga dapat disimpulkan bahwa variabel $C R$ berpengaruh secara nyata terhadap variabel nilai perusahaa. Kemudian nilai probabilitas ROA lebih kecil dari konstanta $(0.0002<0.05)$ maka hasilnya terdapat pengaruh signifikan dari variabel $\mathrm{CR}$ secara individual terhadap nilai perusahaan. 
Tabel 4.7

\section{Pengaruh Nilai Perusahaan terhadap DPR}

\begin{tabular}{|c|c|c|c|c|}
\hline \multicolumn{5}{|c|}{$\begin{array}{l}\text { Dependent Va riable: LOGDPR } \\
\text { Meth od: Panel Least Squares } \\
\text { Date:09/05/17 Time:00:10 } \\
\text { Sample: } 20132016 \\
\text { Periods included: } 4 \\
\text { Cross-sections included: } 10 \\
\text { Total panel (balanced) observations: } 40\end{array}$} \\
\hline Variable & Coefficient & Std, Error & tStafsfoc & Prob. \\
\hline EPS & $\begin{array}{r}3.638910 \\
-10.18805\end{array}$ & $\begin{array}{l}0.139685 \\
2.299306\end{array}$ & $\begin{array}{r}26.05454 \\
-4.430923\end{array}$ & $\begin{array}{l}0.0000 \\
0.0001\end{array}$ \\
\hline \multicolumn{5}{|c|}{ Efrects Specification } \\
\hline \multicolumn{5}{|c|}{ Cross-section fied (dummy'a riables) } \\
\hline $\begin{array}{l}\text { R-squared } \\
\text { Adiusted R-squared } \\
\text { S.E. of regression } \\
\text { Sum squared resid } \\
\text { Loq likelihood } \\
\text { F-stafisto } \\
\text { Prob(F-ste fistic) }\end{array}$ & $\begin{array}{r}0.647562 \\
0.526032 \\
0.494649 \\
7.095647 \\
-22.16958 \\
5.328406 \\
0.000190\end{array}$ & $\begin{array}{l}\text { Mean depen } \\
\text { S.D. depend } \\
\text { Akaike info } \\
\text { Schwarz crit } \\
\text { Hannan-Qui } \\
\text { Durbin-Wate }\end{array}$ & $\begin{array}{l}\text { ent var } \\
\text { nt var } \\
\text { iterion } \\
\text { rion } \\
\text { n citer. } \\
\text { on stat }\end{array}$ & $\begin{array}{l}3.128190 \\
0.718493 \\
1.658479 \\
2.522921 \\
1.826407 \\
2.054061\end{array}$ \\
\hline
\end{tabular}

(Sumber: Hasil Eviews 9/diolah sendiri, 2017)

Berdasarkan hasil perhitungan dengan menggunakan eviews yang ditunjukkan tabel 4.7 diatas, nilai $F$ hitung yaitu sebesar 5,328406, sementara $F$ tabel dengan tingkat $=5 \%$ dan df1 $(\mathrm{k}-1)=(2-1)=1$ dan df2 $(n-k)=(40-2)=38$ didapat $F$ tabel 4,10. Dengan demikian $\mathrm{F}$ hitung $>\mathrm{F}$ tabel $(5,328406>4,10)$ jadi Ho ditolak dan Ha diterima dapat disimpulkan bahwa variabel nilai perusahaan memiliki pengaruh terhadap variabel DPR. Kemudian terlihat dari nilai probabilitas (prob). Sebesar 0,000190 yang lebih kecil dari 0,05 sehingga Ho ditolak dan Ha diterima sehingga nilai perusahaan mempunyai pengaruh dan signifikan terhadap DPR.

\section{b. Pengujian secara simultan (Uji F)}

Menurut (Priyatno,2012:55-56) Uji F digunakan untuk menguji pengaruh variabel independen secara bersama-sama terhadap variabel dependen. Apabila nilai $F$ hitung $>F$ tabel, maka Ho ditolak dan dapat disimpulkan bahwa variabel independen secara simultan berpengaruh atau mempengaruhi variabel dependennya. Apabila $F$ hitung $<F$ tabel, maka Ho diterima dan dapat disimpulkan bahwa tidak ada variabel independen yang berpengaruh atau mempengaruhi variabel dependennya. Apabila nilai prob. $F$ hitung (ditunjukkan pada prob) < dari tingkat kesalahan (a) sebesar 0,05 maka dapat dikatakan bahwa variabel independen berpengaruh signifikan terhadap variabel dependen. 
Tabel 4.8

Pengaruh ROA, ROE, dan CR terhadap Nilai Perusahaan

\begin{tabular}{|c|c|c|c|c|}
\hline \multicolumn{5}{|c|}{$\begin{array}{l}\text { Cependent Variabie: NHAI_PERUSAHAAN } \\
\text { Method: Panel EGLS (Oross-section randon etfecte) } \\
\text { Eate: } 0907 / 17 \text { T me: } 21: 15 \\
\text { Sample: } 20132013 \\
\text { Feriods included: } 4 \\
\text { Cross sections induded } 10 \\
\text { Total panel (balansed) cbservabons: } 40 \text {. } \\
\text { Swamy and Arcra escimator of comoonent variances }\end{array}$} \\
\hline Variabie & Coefficert & Stei: Error & t-Statistic & Prcb. \\
\hline $\begin{array}{c}C \\
R O A \\
R O E \\
C R\end{array}$ & $\begin{array}{r}-0.008370 \\
-0.004763 \\
0.003111 \\
0.025279\end{array}$ & $\begin{array}{l}0.012682 \\
0.001938 \\
0.000603 \\
0.005145\end{array}$ & $\begin{array}{r}-2.891567 \\
-2.458286 \\
5.155378 \\
4.913873\end{array}$ & $\begin{array}{l}0.0085 \\
0.0189 \\
0.0000 \\
0.0000\end{array}$ \\
\hline \multicolumn{5}{|c|}{ Effecte Specification } \\
\hline $\begin{array}{l}\text { Cross-section random } \\
\text { loliosyncrafo random }\end{array}$ & & & $\begin{array}{l}0.034287 \\
0.023799\end{array}$ & $\begin{array}{l}0.2644 \\
0.7366\end{array}$ \\
\hline \multicolumn{5}{|c|}{ Weignted Stajstics } \\
\hline $\begin{array}{l}\text { F-squared } \\
\text { Adjusted R-squared } \\
\text { S.E: of regression } \\
\text { F-statistic } \\
\text { Frob(F-statistic: }\end{array}$ & $\begin{array}{l}0.689788 \\
0.682351 \\
0.023138 \\
26.55368 \\
0.000309\end{array}$ & \multicolumn{2}{|c|}{$\begin{array}{l}\text { Mean depen den: ver } \\
\text { S.D. de perd ent ar } \\
\text { Sum squared resid } \\
\text { Durbin-Wateon stat }\end{array}$} & $\begin{array}{l}0.032233 \\
0.039548 \\
0.019273 \\
1.685748\end{array}$ \\
\hline \multicolumn{5}{|c|}{ Unweighied Statetics } \\
\hline $\begin{array}{l}\text { R-squared } \\
\text { Sure squared resid }\end{array}$ & $\begin{array}{l}0.708692 \\
0.024761\end{array}$ & $\begin{array}{l}\text { Mean depend } \\
\text { Durbin-Wated }\end{array}$ & $\begin{array}{l}\text { ver } \\
\text { Etat }\end{array}$ & $\begin{array}{l}0.060325 \\
1.319570\end{array}$ \\
\hline
\end{tabular}

(Sumber. Hasit Evie w5 9/ dioiahsendi, 2017)

Berdasarkan tabel 4.8 hasil perhitungan dengan menggunakan eviews yang ditunjukkan tabel 4.8 diatas, nilai $F$ hitung yaitu sebesar 26,55868 sementara $F$ tabel dengan tingkat $=5 \%$ dan df $1(k-1)=(4-1)=3$ dan df2 $(n-k)=(40-4)=36$ didapat $F$ tabel 2,87 . Dengan demikian $F$ hitung $>F$ tabel $(26,55868>2,87)$ jadi Ho ditolak dan $\mathrm{Ha}$ diterima dapat disimpulkan bahwa variabel independen secara bersama-sama memiliki pengaruh secara nyata terhadap variabel dependen. Kemudian nilai probabilitas (prob) sebesar 0.000000 yang lebih kecil dari tingkat signifikan 0,05 sehingga Ho ditolak dan $\mathrm{Ha}$ diterima. Hal ini berarti bahwa variabel ROA, ROE dan CR secara bersama-sama atau simultan berpengaruh dan signifikan terhadap nilai perusahaan.

\section{c. Koefisien Determinasi (Adjusted R-Square)}

Uji $\mathrm{R}^{2}$ atau determinasi merupakan suatu ukuran yang penting dalam regresi karena dapat menginformasikan baik atau tidaknya model regresi yang terestimasi atau dengan kata lain angka tersebut dapat mengukur seberapa dekatkah garis regresi yang terestimasi dengan data sesungguhnya. Koefisien ini menunjukkan seberapa besar persentase variabel independen yang digunakan dalam model mampu menjelaskan variabel dependen. Koefisien determinasi ROA, ROE dan CR dapat dilihat pada tabel 4.8. Berdasarkan tabel 4.8 besarnya angka Adjusted $R$-Squre adalah 0,662851 berarti bersifat korelasinya sangat kuat. Hal ini menunjukkan bahwa persentase variabel independen terhadap variabel dependen adalah sebesar $66,28 \%$. Sedangkan sisanya $33,72 \%$ lainnya dipengaruhi faktor lain. 


\section{d. Persamaan Model Regresi}

Penelitian dengan regresi data panel digunakan untuk melihat pengaruh antara variabel independen terhadap variabel dependen. Hubungan fluktuasi variabel dependen dan faktor-faktor fundamental yang mempengaruhinya dapat diformulasikan. Berdasarkan Eviews 9 tabel 4.8 diatas, maka diperoleh persamaan model regresi antara variabel ROA, ROE dan CR terhadap nilai perusahaan yaitu sebagai berikut:

$$
Y=-0,036-0,004 R O A+0,003 R O E+0,025 C R
$$

Dari hasil persamaan regresi linier berganda di atas dapat di analisis sebagai berikut:

1. Konstanta sebesar $-0,036$ menyatakan bahwa jika variabel bebas (ROA, ROE dan CR) dianggap konstan, maka nilai pendapatan bunga sebesar -0,036.

2. Koefisien regresi sebesar $-0,004$ menyatakan bahwa setiap penambahan ROA sebesar $1 \%$ maka akan meningkatkan nilai pendapatan bunga sebesar -0,4.

3. Koefisien regresi sebesar 0.003 menyatakan bahwa setiap penambahan ROE sebesar 1\% maka akan menurunkan nilai pendapatan bunga sebesar 0,3.

4. Koefisien regresi sebesar 0,025 menyatakan bahwa setiap penambahan CR sebesar $1 \%$ maka akan meningkatkan nilai pendapatan bunga sebesar 0,25.

\section{G. Kesimpulan}

Berdasarkan hasil pengujian dan analisis yang telah dilakukan, maka dapat disimpulkan sebagai berikut:

1. Hasil pengujian hipotesis pengaruh ROA terhadap nilai perusahaan menyatakan bahwa ROA mempunyai pengaruh dan signifikan terhadap variabel nilai perusahaan.

2. Hasil pengujian hipotesis pengaruh ROE terhadap nilai perusahaan menyatakan bahwa ROE berpengaruh dan signifikan terhadap variabel nilai perusahaan.

3. Hasil pengujian hipotesis pengaruh $\mathrm{CR}$ terhadap nilai perusahaan menyatakan bahwa CR berpengaruh dan signifikan terhadap variabel nilai perusahaan.

4. Hasil pengujian hipotesis pengaruh penyaluran ROA, ROE dan CR terhadap nilai perusahaan secara simultan menyatakan bahwa variabel penyaluran $R O A, R O E$ dan CR secara simultan atau bersama-sama berpengaruh dan signifikan terhadap variabel nilai perusahaan.

5. Hasil pengujian hipotesis dampak nilai perusahaan terhadap DPR menyatakan bahwa nilai perusahaan berpengaruh dan signifikan terhadap DPR. 


\section{H. Daftar Pustaka}

Atmaja. (2008). Teori dan Praktek Manajemen Keuangan. Yogyakarta: ANDI.

Brigham\&Houston. (2007). Dasar-dasar Manajemen Keuangan. Jakarta: Salemba Empat.

Deitiana. (2013). Manajemen Operasional Strategi dan Analisa Services dan Manufaktur. Jakarta: Jurnal Bisnis dan Akuntansi 15.

DJ, A. M. (2011). Pengaruh Kinerja Keuangan Terhadap Nilai Perusahaan Pada Perusahaan Manufaktur Di BEI. Denpasar.

Fahmi. (2013). Analisis Laporan Keuangan.

Ghozali, I. (2003). Teori Akuntansi. Semarang: BP UNDIP.

HaryadiSarjonodanWindaJulianita. (2011). SPSS vs LISREL:Sebuah Pengantar, Aplikasi untuk Riset . Salemba Empat.

JSP, K. (2003). Pengaruh ROA, ROE, EPS. Profit Margin, Assets Turnover, Rasio Leverage dan DER terhadap Return Saham Pada Perusahaan LQ 45 di BEI.

Julianita, H. S. (2011). SPSS vs LISREL:Sebuah Pengantar, Aplikasi untuk Riset. Salemba Empat.

Jumingan. (2008). Analisis Laporan Keuangan.

Meythi, M. d. (2012). Pengaruh Profitabilitas Dan. Kesempatan Investasi Terhadap Kebijakan Dividen Tunai.

Munawir. (2010). Analisis Laporan Keuangan.

Priyatno, D. (2012). Cara Kilat Belajar Analisis Data dengan SPSS 20. Yogyakarta: Andi.

Priyatno, D. (2008). Mandiri Belajar SPSS untuk Analisis Data dan Uji Statistik. Yogyakarta: Andi.

Sawir, A. (2009). Analisa Kinerja Keuangan dan Perencanaan Keuangan. Jakarta: PT. Gramedia Pustaka Utama.

Suliyanto. (2011). Ekonometrika Terapan Teori dan Aplikasi dengan SPSS. Yogyakarta: CV Andir Offset.

Sutrisno. (2007). Manajemen Keuangan Teori, Konsep, dan Aplikasi.

Winarno. (2015). Analisis Ekonometrika dan Statistika dengan Eviews edisi 4. Yogyakarta: UPP STIM YKPN. 